\title{
The influence of intellectual capital on financial performance in sharia banking companies
}

\author{
Eka Nuraini, Restu Hayati \& Fitra Yulandi \\ Universitas Islam Riau, Pekanbaru, Indonesia
}

\begin{abstract}
This study aims to examine the effect of Intellectual Capital (VAIC) with Value Added Capital Employed (VACA), Value Added Human Capital (VAHU), Structural Capital Employed (STVA), and Rate of Growth of Intellectual Capital (ROGIC) on the variable of Company's financial performance with the indicator of Return On Assets (ROA), Asset Turn Over (ATO), and Growth in Revenue (GR) in sharia banking companies in Indonesia. The sampling technique used was purposive sampling with 10 samples over the observation period of 3 (three) years. Data analysis was done by Partial Least Square (PLS) method. The results showed that the Intellectual Capital (VAIC) variables affect the variable Financial Performance in 3 (three) years of observation. However, the ROGIC analysis (Rate of Growth of Intellectual Capital) on future financial performance showed unaffected results.

Keywords: intellectual capital, human capital, structural capital employed, rate of growth of intellectual capital
\end{abstract}

\section{INTRODUCTION}

Sharia banking is a rapidly growing industry in Indonesia today. Nowadays, almost all conventional banks in Indonesia have subsidiaries in sharia system or business unit. This is done to maintain the company's competitive advantage in the national banking market. As the country with the largest Muslim population in the world, it gives a market opportunity for Indonesia's banking sector. However, the reality of sharia banking has not been able to show the optimal performance over the observation period of 2013-2015. Compared to conventional banking, the level of performance of sharia banking is still far behind. In fact, the performance of most sharia banking has declined over the observation period of 2013-2015.

Financial performance is a company achievement shown in its financial statements (Subkhan \& Citraningrum 2010). Assessment of the financial performance of a company can be done by analyzing the financial statement to determine the condition of the company in a periodical basis, through financial ratios such as Return On Asset (ROA). In the financial statement, there is some other information that has not been submitted to users about the existence of the company's value added. The value-added gener- ally comes from innovation, discovery, knowledge, and development of employees and good relationships with consumers, which is often known as knowledge capital or intellectual capital. Intellectual Capital is a component owned by a company in measuring the value of human resources in it. The changes in the world's economic conditions making knowledge-based resource as a major factor in the sustainability of competition among companies today (Ting \& Lean 2009).

Human Resource also becomes one of the important factors to improve the financial performance of a company. The success of creating the value of a product lies not in factories and buildings but lies in the human mind that contributes to the value creation of the product. Chen et al. (2005) used the Public (VAIC) model to examine the relationship between intellectual capital with market value and financial performance of firms in Taiwan. The results show that intellectual capital positively affects the market value and financial performance of the company. Ting \&Lean (2009) also proved that there is a positive relationship between Intellectual Capital with financial performance (ROA) in Malaysia. While the financial performance of sharia banks in Indonesia decreases (from ROA 2013-2015), this study tested whether it is caused by lack of human 
resources as measured by the intellectual capital factor. The purpose of this study was to analyze of intellectual capital (VAIC) and its growth in company performance.

\section{LITERATURE REVIEW}

\subsection{Intellectual Capital}

There are three main constructs of IC (Bontis et al. 2000), namely: human capital (HC), structural capital (SC), and customer capital (CC). HC simply represents the individual knowledge stock of an organization represented by its employees. $\mathrm{HC}$ is a combination of genetic inheritance; education; experience, and attitude about life and business.

Value Added Capital Employed (VACA) coefficient shows the contribution made by each unit of capital employed to the value-added organization (Ulum et al. 2008). VACA is the ability of companies in managing resources in the form of capital assets in order to improve the financial performance of the company. Hudson (1993) defines physical capital as a material used as input in the production of future goods and services.

Value Added Human Capital (VAHU) shows the contribution made by each Indonesian Rupiah invested by human capital in the value added of the organization. Human capital represents the individual knowledge stock of an organization represented by its employees (Bontis et al. in Ulum 2008).

Structural capital is the ability of the organization or company in fulfilling the company's routine processes and structures that support employee efforts to produce optimal intellectual performance and overall business performance, such as company operating system, manufacturing process, organizational culture, management philosophy, and all form of intellectual properties owned by the company (Sawarjuwono et al. 2003).

The VAIC indicates an intellectual ability of an organization that may also be considered a Business Performance Indicator (BPI). VAIC is the sum of the 3 previous components, namely: VACA, VAHU, and STVA (Firer \& Williams 2003).

In this study, the authors use variables contained in intellectual capital, and this variable uses the method of Value Added Intellectual Coefficient (VAIC), namely: Human Capital Efficiency (HCE), Structural Capital Efficiency (SCE), and Capital Employed Efficiency (CEE).

$\mathrm{HCE}$ is the experience, skill, and experience of employees who are taken away from the company, generated through competence, attitudes, and intellectual intelligence. SCE includes non-human storehouses of knowledge within the organization. CEE is a company's ability in managing resources in the form of capital assets that if managed properly in order to improve the performance of the company.

\subsection{Financial Performance}

Company performance is a description of the financial condition of a company that is analyzed with the tools of financial analysis in order to know the bad state of a company's financial performance that reflects the performance within a certain period.

Return on asset (ROA) reflects the business benefits and efficiency of the company in the utilization of total assets (Chen et al. 2005). This ratio represents the profitability ratio, which measures the company's ability to generate profits utilizing the firm's total assets. The higher the value of ROA was more efficient the company in using its assets, both physical assets and non-physical assets (intellectual capital) to generate profits for the company.

Asset Turnover (ATO) is the ratio of total revenue to total assets (Firrer \& William 2003). This ratio measures the efficiency of the use of total assets in generating revenue. Higher utilization of total asset usage of tangible assets and intangible assets such as intellectual capital owned will increase the company's revenue (Sawarjuono \& Kadir 2003).

Growth revenue ratio measures the change in corporate earnings, how well the company maintains its economic position. Increased revenue is usually a signal for companies to grow and develop (Chen et al. 2000). The better the company can process and utilize the intellectual capital owned will provide more value and competitive advantage for the company so that the company's revenue will also increase.

\section{THEORETICAL FRAMEWORK}

The Relationship between intellectual capital and financial and financial performance the intellectual capital relationship with the company's financial performance has been empirically verified by several researchers in various approaches in several countries. Bontis (1998) in Ulum (2007 initiated research on ICs by exploring relationships among IC components (human capital, customer capital and structural capital). The study used questionnaires and grouped industry in service and non service categories. Most research on IC uses secondary data in the form of financial statements (annual). Some researchers use VAIC, either to measure the performance of the IC itself or to see the relationship between IC and the company's financial performance. 
Research Hypothesis: H1: There is a positive influence of Intellectual Capital (VAIC) on the company's financial performance; $\mathrm{H} 2$ : There is a positive influence of Intellectual Capital (VAIC) on the future financial performance of the company; and H3: There is a positive effect of intellectual capital growth (ROGIC) on the future financial performance of the company.

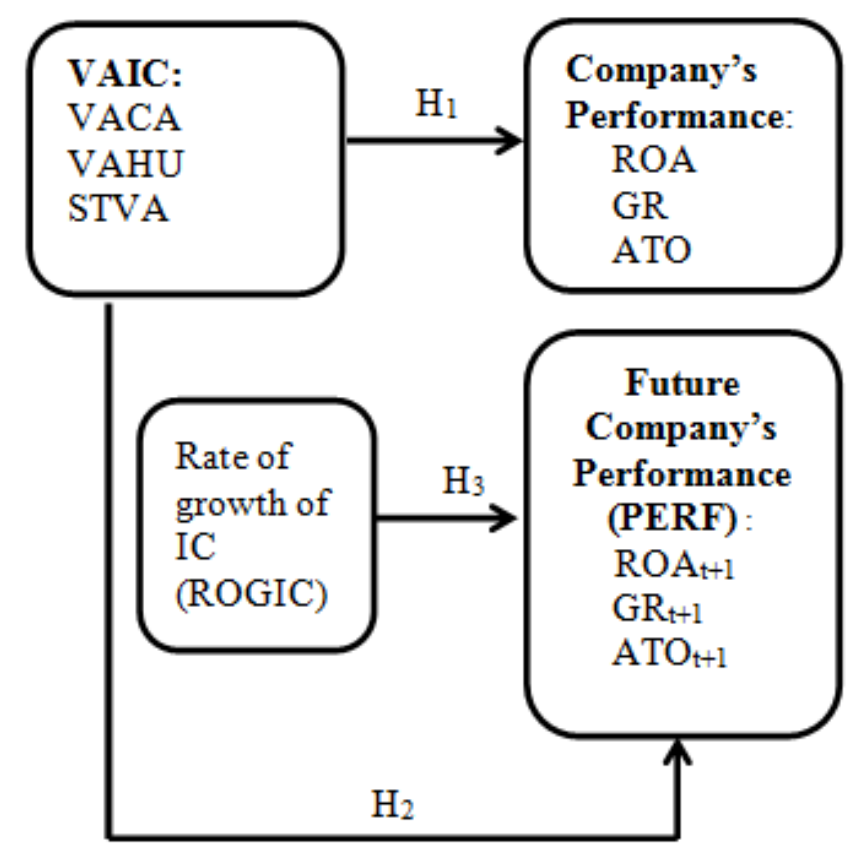

Figure 1. Framework.

\section{METHODS}

The population used in this study was sharia banking companies operating in Indonesia over the period 2013 to 2015 with purposive sampling. The criteria used in the sampling were the company that had a positive average ROA and published their full annual financial statements over the period of 2013 to 2015.

\section{FINDING AND DISCUSSION}

Inner model or structural model testing is done to see the relationship between construct, significance value, and $\mathrm{R}$-square of the research model. The structural model is evaluated using $\mathrm{R}$-square for dependent constructs, Stone-Geisser Q-square test for predictive relevance and t-test as well as the significance for the structural path parameter coefficients. Based on Table 1, it is known that in year 2013, IC had an effect on the financial performance of sharia banking company in Indonesia with inner weight value equal to 0.722 and t-statistic value 3,840 (significant at $\mathrm{p}<0.01$ ). This also happened in 2014 and 2015 which gave significant results. The effect of IC on financial performance in 2014 had an inner weight value of 0.765 and t-statistic of 7.124 (significant at $\mathrm{p}<0.01$ ), and in 2015 had an inner weight of 0.337 and t-statistic of 1.514 (significant at $p<0.10$ ). The first hypothesis is accepted showing that higher intellectual capital owned by the company then the company will be able to create value added to then boost the company's financial performance.

Table 1. Inner Weight Value.

\begin{tabular}{lcccc}
\hline Variabe & $\begin{array}{l}\text { Original } \\
\text { Sample } \\
\text { Estimate }\end{array}$ & t-stat & Std Dev & Decision \\
\hline $\begin{array}{l}\text { VAIC'13 } \\
\rightarrow \text { KK'13 }\end{array}$ & 0.72 & $3.84 * * *$ & 0.19 & H1 Accepted \\
$\begin{array}{l}\text { VAIC'14 } \\
\rightarrow \text { KK'14 }\end{array}$ & 0.77 & $7.12^{* * *}$ & 0.11 & H1 Accepted \\
$\begin{array}{l}\text { VAIC'15 } \\
\rightarrow \text { KK'15 }\end{array}$ & 0.34 & $1.51^{*}$ & 0.22 & H1 Accepted \\
$\begin{array}{l}\text { VAIC'13 } \\
\rightarrow \text { KK'14 }\end{array}$ & -0.17 & 0.23 & 0.75 & H2 Rejected \\
$\begin{array}{l}\text { VAOC'14 } \\
\rightarrow \text { KK'15 }\end{array}$ & 0.90 & $4.76^{* * * *}$ & 0.19 & H2 Accepted \\
$\begin{array}{l}\text { ROGIC'13-14 } \\
\rightarrow \text { KK'14 }\end{array}$ & 0.60 & 0.85 & 0.70 & H3 Rejected \\
$\begin{array}{l}\text { ROGIC'14-15 } \\
\rightarrow \text { KK'15 }\end{array}$ & 0.01 & 0.25 & 0.29 & H3 Rejected \\
\hline
\end{tabular}

* significant at $\mathrm{p}<0.10 ; * * \mathrm{p}<0.05 ; * * * \mathrm{p}, 0.01$ (1-tailed).

The observation of IC in 2013 to financial performance in 2014 resulted in inner weight value data of -0.17 and t-statistic value of 0.23 (not significant). This indicates that in 2013, the IC did not affect the future financial performance in 2014, as well as findings on IC observation in 2014 to the financial performance of 2015, which shows the value of the inner weight of 0.90 and at t-statistic of 4775 (significant at $\mathrm{p}<0.01$ ). This shows that in the year 2014, the IC affected the future financial performance of 2015.

The influence of ROGIC 2013 to the financial performance of 2014 has an inner weight of 0.60 and t-statistic of 0.85 (not significant). The third hypothesis is accepted that the influence of ROGIC 2014 to 2015 on the performance of the financial year 2015 has an inner weight of 0.07 and t-statistic of 0.25 which also means insignificant. It concludes that the higher average growth rate of the Intellectual Capital (rate of growth of intellectual capital of ROGIC) has no effect on future financial performance and vice versa. 


\section{CONCLUSION}

IC (VAIC) affects the financial performance of sharia banking companies in Indonesia. IC was tested to the company's financial performance in the same year. Based on the results, there is a significant influence between IC (VAICTM) on the financial performance of sharia banking company in Indonesia for the year 2013, 2014, and 2015.

IC (VAIC) affects the financial performance of the future of sharia banking companies in Indonesia. Statistically, there is an effect of IC (VAICTM) on the financial performance of the future of sharia banking companies in Indonesia for 2014-2015. However, 2013-2014 indicates that there is no statistically significant influence of IC (VAIC) on the financial performance of sharia banking companies in Indonesia. It is assumed that intellectual capital influence to financial performance is only 1 or 2 years and in the long run, intellectual capital has no effect on future company performance.

The average growth of IC (ROGIC) does not affect the financial performance future of sharia banking companies in Indonesia. There is no statistically significant ROGIC effect on the future financial performance of the company in Indonesia, either for the ROGIC 2014-2015 period for financial performance 2014 and 2014-2015 ROGIC for financial performance 2015. The effect of the rate of growth intellectual capital is limited to 1 or 2 years only, and in the long term, the rate of growth of intellectual capital will not affect the future performance of the company. This is due to the development of companies that uses the rate of growth intellectual capital, resulting in the company's difficulty to survive in the long term.

\section{REFERENCES}

Bontis, N., Keow, W.C.C., \& Richardson, S. 2000. Intellectual capital and business performance in Malaysian industries. Journal of Intellectual Capital 1(1): 85-100.

Chen, M.C., Cheng, S.J., Hwang, Y. 2005. An empirical investigation of the relationship between intellectual capital and firms' market value and financial performance. Journal of Intellectual Capital 6(2): 159-176.

Firer, S. \& Williams, M. 2003. Intellectual capital and traditional measures of corporate performance. Journal of Intellectual Capital 4(3): 348-60.

Hudson, W. 1993. Intellectual capital: how to build it, enhance it, use it. New York: John Wiley \& Sons.

Sawarjuono, T. \& Kadir, A.P. 2003. Intellectual capital: perlakuan, pengukuran dan pelaporan (sebuah library research). Jurnal Akuntansi dan Keuangan.

Subkhan \& Citraningrum, D.P. 2010. Pengaruh intellectual capital terhadap kinerja keuangan perusahaan perbankkan di BEI Periode 2005-2007. Jurnal Dinamika Akuntansi 2(1): 48-59.
Ulum, I. 2007. Pengaruh intellectual capital terhadap kinerja keuangan perusahaan publik sektor perbankan. (Unpublished thesis). Universitas Dipenogoro.

Ulum, I., Ghozali, I., \& Chariri, A. 2008. Intellectual Capital dan Kinerja Keuangan Perusahaan; Suatu Analisis dengan Pendekatan Partial Least Squares (PLS). Simposium Nasional Akuntansi. 23-24 Juli 2008. Pontianak: SNA.

Ting, I.W.K. \& Lean, H.H. 2009. Intellectual capital performance of financial institutions in Malaysia. Journal of Intellectual Capital 10(4): 588-599. 